\title{
Effects of Hylomecon vernalis ethanol extracts on cell cycle and apoptosis of colon cancer cells
}

\author{
JING SUN $^{1}$, XIN ZHANG $^{1}$, YANG SUN ${ }^{2}$, ZHI-SHU TANG $^{1}$ and DONG-YAN GUO ${ }^{1}$ \\ ${ }^{1}$ College of Pharmacy, Shannxi University of Chinese Medicine, Xianyang, Shannxi 712046; ${ }^{2}$ Department of \\ Pharmacology, School of Pharmacy, The Fourth Military Medical University, Xi'an, Shannxi 710032, P.R. China
}

Received January 20, 2016; Accepted January 19, 2017

DOI: $10.3892 / \mathrm{mmr} .2017 .6426$

\begin{abstract}
Hylomecon vernalis Maxim. has traditionally been used to promote blood circulation, alleviate pain, dissipate stasis, and reduce swelling. The aim of the present study was to investigate the effect and potential mechanism of H. vernalis Maxim. ethanol extracts (HVMEE) on the growth and apoptosis of human colon cancer HT-29 and SW620 cells. $H$. vernalis samples were extracted three times with ethanol, dried, and concentrated into powder. The components of HVMEE were investigated using high performance liquid chromatography in tandem with mass spectrometry analysis. MTT assay was used to investigate the effect of HVMEE on viability of human colon cancer HT-29 and SW620 cells. Apoptosis of HT-29 and SW620 cells was evaluated using flow cytometric analysis. Expression levels of apoptosis and cell cycle-related proteins were assessed by western blot. The findings demonstrated that the alkaloid content of HVMEE was as high as $89.67 \%$, and it effectively inhibited viability in HT-29 and SW620 cells, with $\mathrm{IC}_{50}$ values of $0.105 \pm 0.022 \mathrm{mg} / \mathrm{ml}$ and $0.146 \pm 0.013 \mathrm{mg} / \mathrm{ml}$, respectively. In addition, HVMEE induced apoptosis in HT-29 and SW620 cells, by increasing caspase-3, caspase- 9 and BCL2 associated X expression, and reducing Bcl-2 expression. The present study suggests that HVMEE has a potential role in the treatment of colorectal cancer.
\end{abstract}

\section{Introduction}

Colorectal cancer (CRC) is one of the most common cancers worldwide, with an annual incidence rate of 1.2 million and an annual mortality rate of over 600,000 individuals $(1,2)$. Despite considerable advances in surgical techniques and neoadjuvant chemotherapy, the survival rate of CRC remains poor (3). Antimetabolites, such as 5-fluorouracil (5-FU), have therapeutic properties for patients with CRC; however, the side

Correspondence to: Dr Jing Sun, College of Pharmacy, Shannxi University of Chinese Medicine, 55 Century Avenue, Xianyang, Shannxi 712046, P.R. China

E-mail: 124613320@qq.com

Key words: Hylomecon vernalis, apoptosis, cancer cell, cell cycle effects, which include myelotoxicity and GI toxicities (such as diarrhea and stomatitis), limit their long-term use. Thus, there is an urgent need for the development of new drugs with more specific effects and low toxicity.

Natural products have been shown to be excellent and reliable sources in pharmaceutical development of anticancer drugs $(4,5)$. Sinomenine (SIN), an alkaloid from Sinomenium acutum, inhibits proliferation in SW1116 colorectal cancer cells by promoting $\mathrm{G}_{1}$ phase arrest, with concomitant suppression of COX-2 expression (6). Bisleuconothine A, a bisindole alkaloid, inhibits cell proliferation and induces apoptosis in HCT116 and SW480 colorectal cancer cells, by increasing caspase cleavage (7). Furthermore, it dramatically suppresses Wnt target gene expression in an in vivo HCT116 xenograft model, through upregulation of $\beta$-catenin phosphorylation and subsequent Wnt signaling inhibition (7). Piperlongumine (PPLGM), an alkaloid isolated from the long pepper (Piper longum L.), selectively triggers cancer cell death in HCT116 colorectal cancer cells, through activation of the JNK signaling pathway (8).

Hylomecon vernalis Maxim. has long been used in traditional Chinese medicine for improving the local blood supply, dissipating blood stasis, and relieving pain. Alkaloids have multiple biological activities, including antitumor, anti-inflammatory, and analgesic effects. In the present study, the aim was to investigate the effect of HVMEE on viability and apoptosis of HT-29 and SW620 human colorectal cancer cells and its potential mechanism.

\section{Materials and methods}

Chemicals and reagents. MTT was purchased from Sigma-Aldrich; Merck Millipore (Darmstadt, Germany). Polyclonal rabbit anti-human cleaved caspase-3 (1:1,000; cat. no. $9661 \mathrm{~S}$ ), monoclonal rabbit anti-human cleaved caspase- 8 (1:1,000; cat. no. 9496S), polyclonal rabbit anti-human cleaved caspase-9 (1:1,000; cat. no. 9505S), monoclonal mouse anti-human BCL-2 (1:1,000; cat. no. 15071S), polyclonal rabbit anti-human Bax (1:1,000; cat. no. 2772S), monoclonal rabbit anti-human cyclin D1 $(1: 1,000$; cat no. 2978S), monoclonal rabbit anti-human CDK4 (1:1,000; cat. no. 12790S), monoclonal rabbit anti-human CDK6 (1:1,000; cat. no. 13331S) and monoclonal rabbit anti-human p21 (1:1,000; cat. no. 2947S) primary antibodies were purchased 
from Cell Signaling Technology, Inc. (Danvers, MA, USA). N-Benzyloxycarbonyl-Val-Ala-Asp (O-Me) fluoromethyl ketone (Z-VAD-FMK) was purchased from Beyotime Institute of Biotechnology (Haimen, China). The monoclonal mouse anti-human $\beta$-actin primary antibody was obtained from Abcam (1:1,000; cat. no. ab8226; Cambridge, UK). Goat anti-mouse and goat anti-rabbit secondary antibodies were purchased from Thermo Fisher Scientific, Inc., (1:5,000; cat. nos. A16072 and A16110, respectively; Waltham, MA, USA).

Extraction of HVMEE. H. vernalis Maxim. was purchased from Shaanxi Panlong Pharmaceutical Co., Ltd. (Shangluo, China). Briefly, the dried root of $H$. vernalis Maxim. (10.0 kg) was extracted with $70 \%$ ethanol three times. The extracts were combined, concentrated, and dried at $80^{\circ} \mathrm{C}$ to obtain the HVMEE. High-performance liquid chromatography (HPLC) in tandem with mass spectrometry analysis was used to assess the main ingredients in the extracts. HPLC was conducted in tandem with mass spectrometry using an Agilent 1260 HPLC and AB SCIEX 4500Q trap triple quadrupole mass spectrometer with ESI source: Mobile phase $0.1 \%(\mathrm{v} / \mathrm{v})(\mathrm{A})$ formic acid aqueous solution and (B) acetonitrile; injection volume $5 \mu \mathrm{l}$; column temperature $35^{\circ} \mathrm{C}$, using a gradient elution mode. Run times from $0-10 \mathrm{~min}$ up to $15 \% \mathrm{~B}$ and from 11-20 min up to $27 \% \mathrm{~B}$. The HPLC system consisted of a C18 column $(3.9 \times 300 \mathrm{~mm}, 10 \mu \mathrm{m})$ with $1 \mathrm{ml} / \mathrm{min}$ flow rate. The MassHunter (Agilent Technologies, Inc., Santa Clara, CA, USA) system was used.

Cell culture. Human CRC cell lines HT-29 and SW620 were obtained from the American Type Culture Collection (Manassas, VA, USA). The cells were cultured in RPMI-1640 (Thermo Fisher Scientific, Inc.) supplemented with $10 \%$ fetal calf serum (Gibco; Thermo Fisher Scientific, Inc.; cat. no. 10437-028), $100 \mathrm{U} / \mathrm{ml}$ penicillin, and $100 \mathrm{U} / \mathrm{ml}$ streptomycin in an atmosphere of $95 \%$ oxygen and $5 \% \mathrm{CO}_{2}$ at $37^{\circ} \mathrm{C}$.

Cell viability assay. HT-29 and SW620 cells were seeded in 96-well plates at a density of $2 \times 10^{4}$ cells/well for $24 \mathrm{~h}$, then cells were treated with $0.01,0.03,0.1,0.3,1$, and $3 \mathrm{mg} / \mathrm{ml}$ HVMEE for $24 \mathrm{~h}$ in complete medium. Following treatment, $20 \mu \mathrm{l}$ of MTT solution $(5 \mathrm{mg} / \mathrm{ml})$ was added to each well for $4 \mathrm{~h}$. The cells were then washed three times with PBS, and the resulting formazan was resuspended in $150 \mu 1$ dimethyl sulfoxide. Absorbance was measured at $570 \mathrm{~nm}$ with a Bio-Rad ELISA reader (Bio-Rad Laboratories, Inc., Hercules, CA, USA). The experiment was repeated independently three times.

Flow cytometric assay for Annexin V apoptosis detection. Cell apoptosis was detected using an Annexin V-fluorescein isothiocyanate (FITC)/propidium iodide (PI) apoptosis detection kit (BD Biosciences, Franklin Lakes, NJ, USA). Briefly, HT-29 and SW620 cells were grown at a density of 5x10 per well in 6-well plates. In accordance with the $\mathrm{IC}_{50}$ values obtained from the MTT assay, the cells were treated with 0.01 or $0.05 \mathrm{mg} / \mathrm{ml} \mathrm{HVMEE} \mathrm{for} 24 \mathrm{~h}$. Using the MTT assay results, the $\mathrm{IC}_{50}$ values were $0.105 \pm 0.022 \mathrm{mg} / \mathrm{ml}$ for HT-29 and $0.146 \pm 0.013 \mathrm{mg} / \mathrm{ml}$ for SW620 cells. The authors identified that the minimum effective concentration of HVMEE was $0.01 \mathrm{mg} / \mathrm{ml}$ for HT-29 and SW620 cells. Therefore, five times the minimum effective concentration of HVEMEE was $0.05 \mathrm{mg} / \mathrm{ml}$, which is a concentration with a significant effect, whilst bearing an apoptosis rate (for both HT-29 and SW620) of $<50 \%$.

Then, a total of $1 \times 10^{6}$ cells were collected with centrifuge $(700 \times \mathrm{g}) 3 \mathrm{~min}$ at room temperature, washed with ice-cold PBS and resuspended in $1 \mathrm{X}$ binding buffer $[10 \mathrm{mM}$ Hepes/ $\mathrm{NaOH}$ (pH 7.4), $\left.140 \mathrm{mM} \mathrm{NaCl}, 2.5 \mathrm{mM} \mathrm{CaCl}_{2}\right]$ at a concentration of $1 \times 10^{6}$ cells $/ \mathrm{ml}$. Annexin V-FITC ( $5 \mu \mathrm{l}$ of a $25 \mu \mathrm{g} / \mathrm{ml}$ solution) and PI (5 $\mu \mathrm{l}$ of a $250 \mu \mathrm{g} / \mathrm{ml}$ solution) were added to $100 \mu \mathrm{l}$ of cell suspension. The cells were then gently vortexed and incubated at room temperature in the dark for $15 \mathrm{~min}$. Then, $400 \mu \mathrm{l}$ of ice-cold binding buffer was added and mixed gently before the cell preparations were examined by flow cytometry (FACSCalibur; BD Biosciences).

Flow cytometric assay for nuclear DNA content distribution detection. To determine cell cycle distribution, cells were collected with centrifuge $(700 \times \mathrm{g}) 3 \mathrm{~min}$ at room temperature, washed with ice-cold PBS and fixed for $2 \mathrm{~h}$ in $75 \%$ ethanol at $-20^{\circ} \mathrm{C}$. The cells were then treated with $1 \%$ RNase A for $5 \mathrm{~min}$ at $37^{\circ} \mathrm{C}$ and stained with $50 \mathrm{mg} / \mathrm{ml} \mathrm{PI}$ for $30 \mathrm{~min}$. Fluorescence intensity was examined by flow cytometry using a FACS Calibur (FACSCalibur; BD Biosciences).

Caspase-3 activity. Caspase-3 activity in HT-29 and SW620 cells was detected using the caspase-3 activity assay kit (Beyotime Institute of Biotechnology), as per the manufacturer's instructions. HT-29 and SW-620 cells were plated in culture dish (diameter, $10 \mathrm{~cm}$ ) at a density of $1 \times 10^{6}$ cells and allowed to grow for $24 \mathrm{~h}$. The cells were then treated with HVMEE and Z-VAD-FMK $(10 \mu \mathrm{M})$ for $24 \mathrm{~h}$ or $48 \mathrm{~h}$ in complete medium with $37^{\circ} \mathrm{C}$. Following drug treatment, absorbance values were measured at $405 \mathrm{~nm}$. Results were adjusted to the total protein content, and activity was expressed as nmol of p-Nitroaniline per mg of total protein.

Western blot analysis. HT-29 and SW-620 cells were plated in culture dish (diameter, $10 \mathrm{~cm}$ ) at a density of $10 \times 10^{6}$ cells and allowed to grow for $24 \mathrm{~h}$. Then, HT-29 cells and SW620 cells were treated with 0.01 and $0.05 \mathrm{mg} / \mathrm{ml} \mathrm{HVMEE}$ for 24 and $48 \mathrm{~h}$. The cells were then collected with a centrifuge $(700 \times \mathrm{g})$ 3 min at room temperature, and resuspended in lysis buffer (Beyotime Institute of Biotechnology) for $30 \mathrm{~min}$ in an ice bath. Following centrifugation at $14,000 \times \mathrm{g}$ at $4^{\circ} \mathrm{C}$ for $30 \mathrm{~min}$, the supernatant was collected. Protein concentrations were determined using the Bradford method. Equal protein amounts $(30 \mu \mathrm{g})$ were separated by $15 \%$ sodium dodecyl sulfate polyacrylamide gel electrophoresis, transferred electrophoretically to nitrocellulose membranes (Pall Corporation, New York, NY, USA) and blocked with TBS buffer containing $0.05 \%$ Tween-20 and $10 \%$ non-fat milk for $2 \mathrm{~h}$ at room temperature. The membranes were then incubated overnight at $4^{\circ} \mathrm{C}$ with various primary antibodies, followed by horseradish peroxidase-conjugated secondary antibodies at room temperature for $1.5 \mathrm{~h}$. Following washing the membranes three times for $5 \mathrm{~min}$ in TBS buffer containing $0.05 \%$ Tween-20. Immunoreactive proteins on the membrane were detected using the Immobilon Western HRP substrate (EMD Millipore, Billerica, MA, 


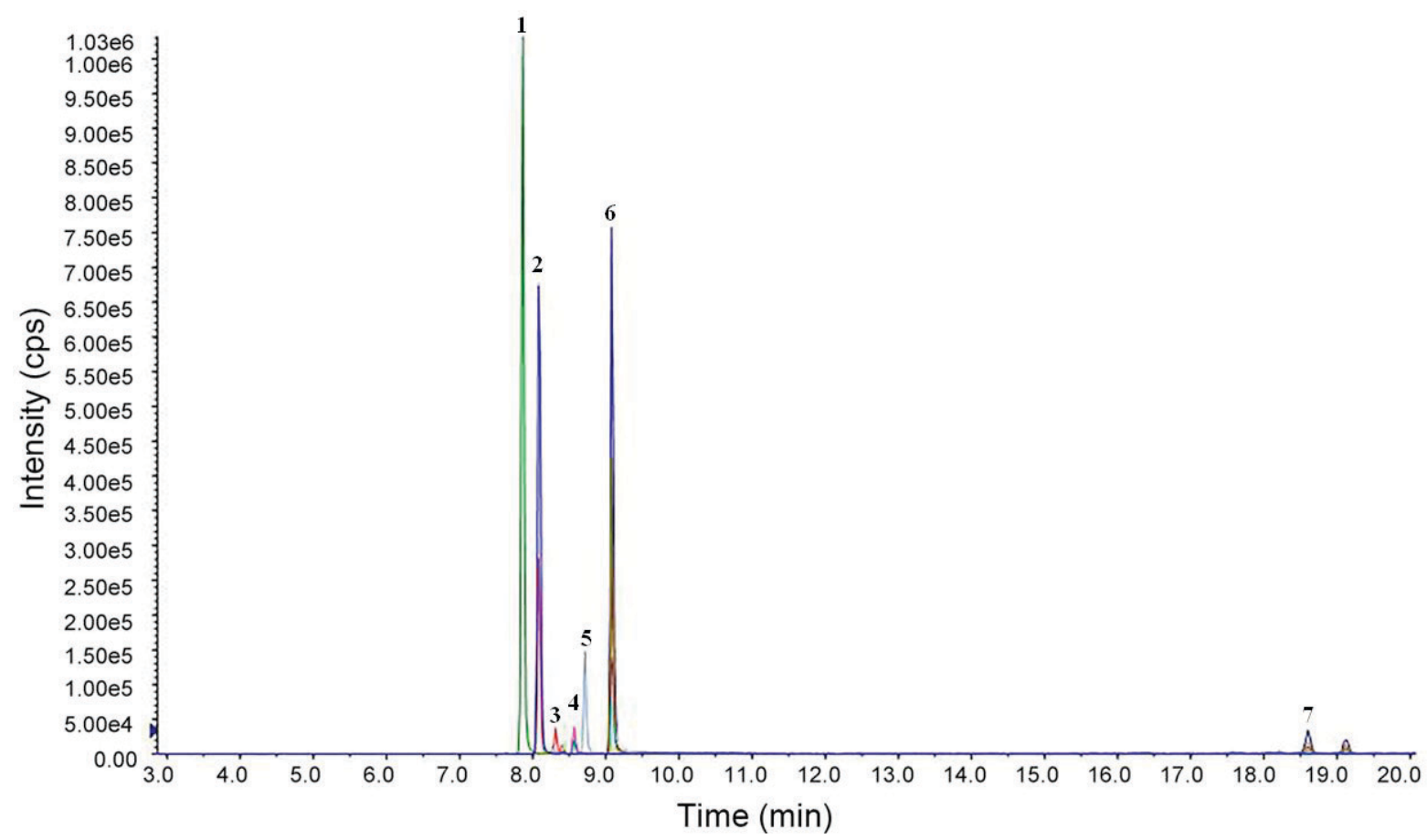

Figure 1. Total ion chromatogram of the sample solution. Cps, counts per second; 1, protopine; 2, allocryptopine; 3 , berberine; 4 coptisine; 5 , chelerythrine; 6, sanguinarine; 7, Ttetrahydroberberine.

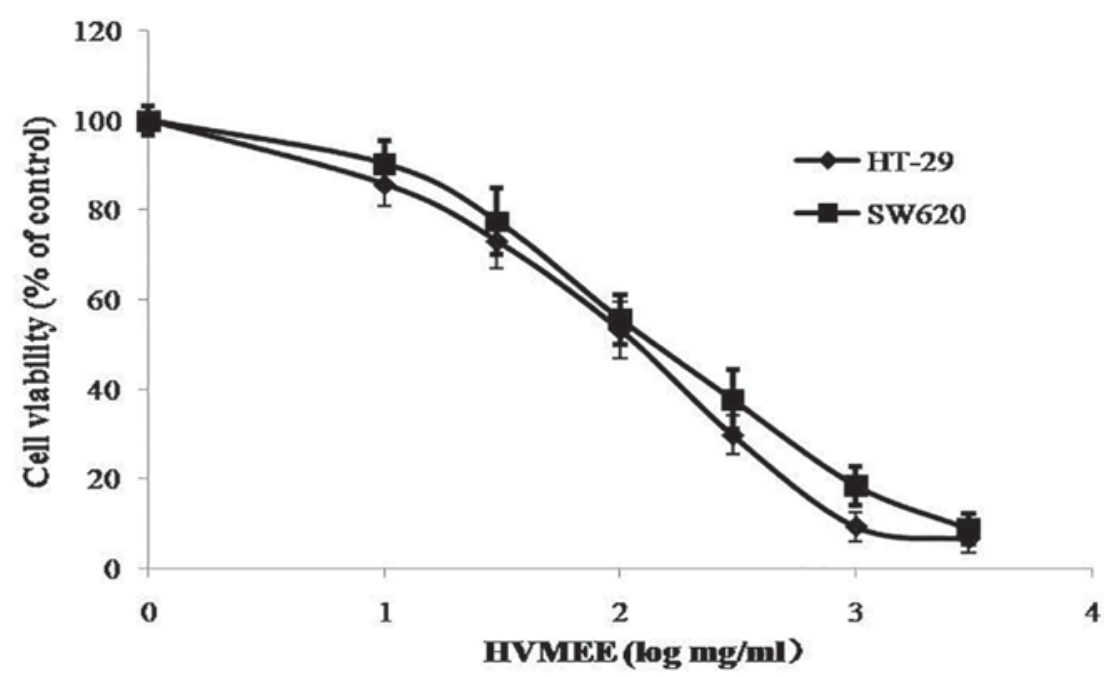

Figure 2. Effect of HVMEE treatment on colorectal cancer cell viability. Cell viability was measured by MTT assay in HT-29 and SW620 cells treated with 0 , $0.01,0.03,0.1,0.3,1$, and $3 \mathrm{mg} / \mathrm{ml} \mathrm{HVMEE}$ for $24 \mathrm{~h}$. Data are presented as \% of live cells relative to control untreated cells. $\mathrm{n}=3$ independent repeats. HVMEE, Hylomecon vernalis Maxim. ethanol extract.

USA). The bands were quantified using Multi Gauge version 3.2 software (Fujifilm Holdings Corporation, Tokyo, Japan). Experiments were repeated independently 3 times, and the relative expression of the target protein was normalized to the level of $\beta$-actin in the same sample.

Statistical analysis. SPSS software (version, 13.0; SPSS, Inc., Chicago, IL, USA) was used for the statistical analysis. Data were expressed as the mean \pm standard deviation. Statistical analyses were carried out using a one-way analysis of variance and Fisher's least significant difference (LSD) $t$-test to compare differences between groups. $\mathrm{P}<0.05$ was considered to indicate a statistically significant difference.

\section{Results}

Results of mass spectrometry. Ion flow results from HPLC analysis of the HVMEE are demonstrated in Fig. 1. The alkaloid content of the HVMEE was as high as $89.67 \%$. The principal alkaloids observed were allocryptopine, protopine, berberine, sanguinarine, chelery thrine, tetrahydroberberine, and coptisine; their relative contents were 13.48, 55.33, 0.16, 14.86, 5.81, 0.002, and 0.02\%, respectively (Fig. 1).

HVMEE decreases viability in HT-29 and SW620 cells. The effect of HVMEE on cell viability was assessed by MTT assay. As demonstrated in Fig. 2, HVMEE effectively decreased cell 

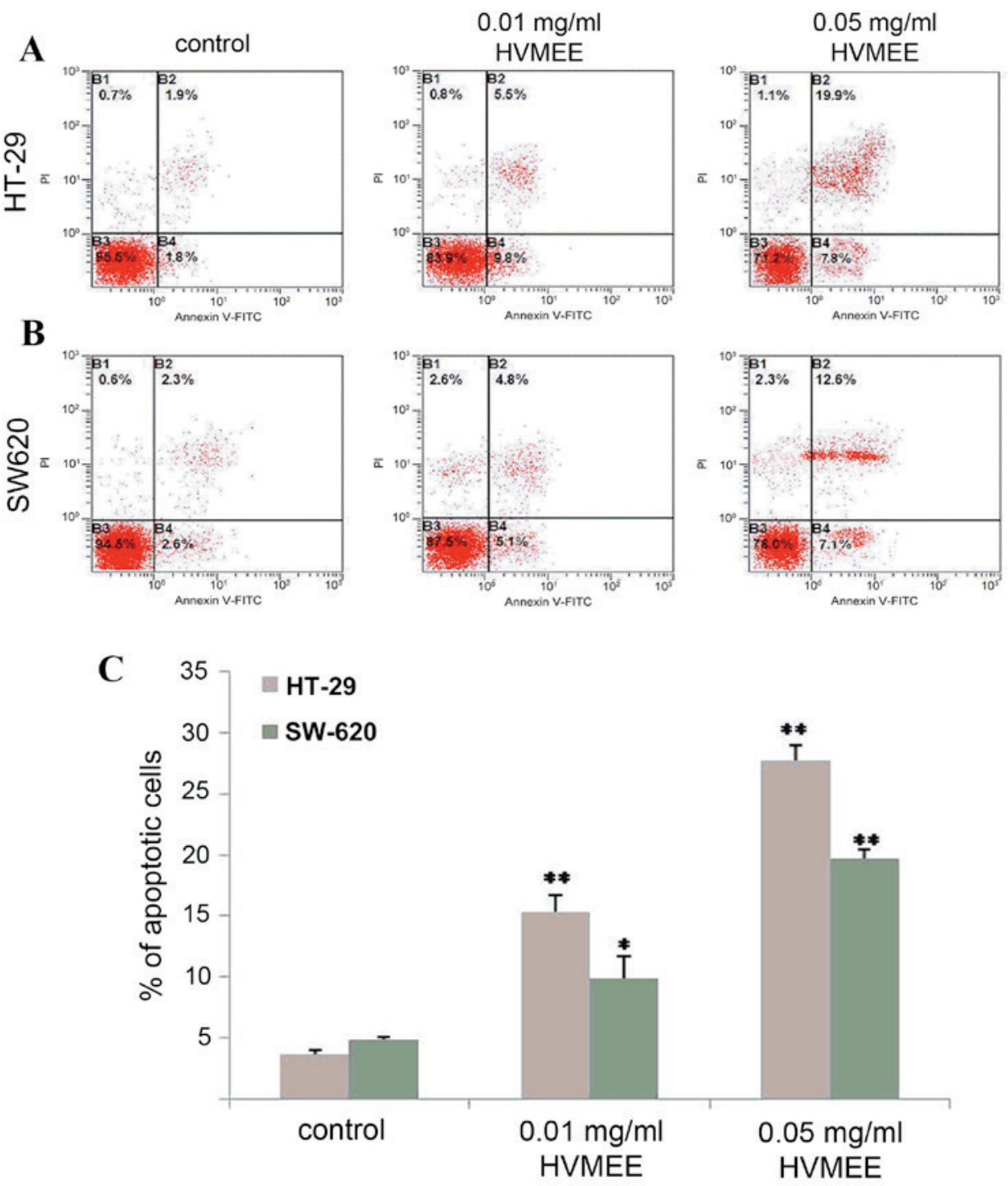

Figure 3. Effect of HVMEE treatment on apoptosis. (A) HT-29 and (B) SW620 cells were treated with $0,0.01 \mathrm{or} 0.05 \mathrm{mg} / \mathrm{ml} \mathrm{HVMEE} \mathrm{for} 24 \mathrm{~h}$, and apoptosis was detected using Annexin V-FITC/PI staining and flow cytometry analysis. (C) Quantification of apoptotic cells as \% of total (sum of B2 and B4 quadrants). The experiment was repeated independently three times. ${ }^{*} \mathrm{P}<0.05$ and ${ }^{* *} \mathrm{P}<0.01$ vs. untreated control cells. HVMEE, Hylomecon vernalis Maxim. ethanol extract; B1, necrotic cells; B2, cells at end stage of apoptosis; B3, viable cells; B4, cells at the early stage of apoptosis; FITC, fluorescein isothiocyanate; PI, propidium iodide.

viability in HT-29 and SW620 cells in a concentration-dependent manner. The $\mathrm{IC}_{50}$ values were $0.105 \pm 0.022 \mathrm{mg} / \mathrm{ml}$ for HT-29 and $0.146 \pm 0.013 \mathrm{mg} / \mathrm{ml}$ for SW620 cells (Fig. 2).

HVMEE treatment triggers cell apoptosis. Apoptosis of HVMEE colorectal cancer cells was assessed by flow cytometry analysis. As demonstrated in Fig. 3, the percentages of apoptotic cells (the sum of B2 and B4 quadrants of the flow cytometry plots) in the untreated control HT-29 (Fig. 3A) and SW620 cells (Fig. 3B) were $3.7 \pm 0.3 \%$ (Fig. 3A and C) and $4.9 \pm 0.2 \%$ (Fig. 3B and C), respectively. When exposed to $0.01 \mathrm{mg} / \mathrm{ml} \mathrm{HVMEE}$ for $24 \mathrm{~h}$, the percentage of apoptotic cells increased to $15.3 \pm 1.4 \%$ in the HT-29 cells $(\mathrm{P}<0.01$; Fig. $3 \mathrm{~A}$ and $\mathrm{C})$ and $9.9 \pm 1.8 \%$ in the SW620 cells $(\mathrm{P}<0.05$; Fig. 3B and C). When exposed to $0.05 \mathrm{mg} / \mathrm{ml}$ of HVMEE for $24 \mathrm{~h}$, the percentages of apoptotic cells increased to $27.7 \pm 1.3 \%$ in the HT-29 cells $(\mathrm{P}<0.01$; Fig. $3 \mathrm{~A}$ and $\mathrm{C})$ and $19.7 \pm 0.7$ in the SW620 cells $(\mathrm{P}<0.01$; Fig. 3B and $\mathrm{C})$. In addition, treatment of HT-29 and SW620 cells with 0.01 and $0.05 \mathrm{mg} / \mathrm{ml} \mathrm{HVMEE}$ resulted in a significant increase in caspase- 3 activation in both cell lines compared with untreated control (Fig. 4). The HVMEE-induced caspase-3 activity was significantly blocked by pretreatment with a general caspase inhibitor, Z-VAD-FMK (Fig. 4).

HVMEE induces cell cycle arrest at the $G_{1}$ phase in HT-29 and SW620 cells. The cell cycle phase distribution in HT-29 (Fig. 5A) and SW620 (Fig. 5B) cells was examined following treatement with 0.01 and $0.05 \mathrm{mg} / \mathrm{ml} \mathrm{HVMEE}$ for $24 \mathrm{~h}$. Flow cytometric analysis of nuclear DNA distribution demonstrated a concentration-dependent increase of $\mathrm{G}_{1}$ proportions in HVMEE-treated cells, compared with untreated control cells (Fig. 5).

HVMEE affects apoptosis-related protein expression. Following 24 and $48 \mathrm{~h}$ of 0.01 and $0.05 \mathrm{mg} / \mathrm{ml}$ HVMEE 


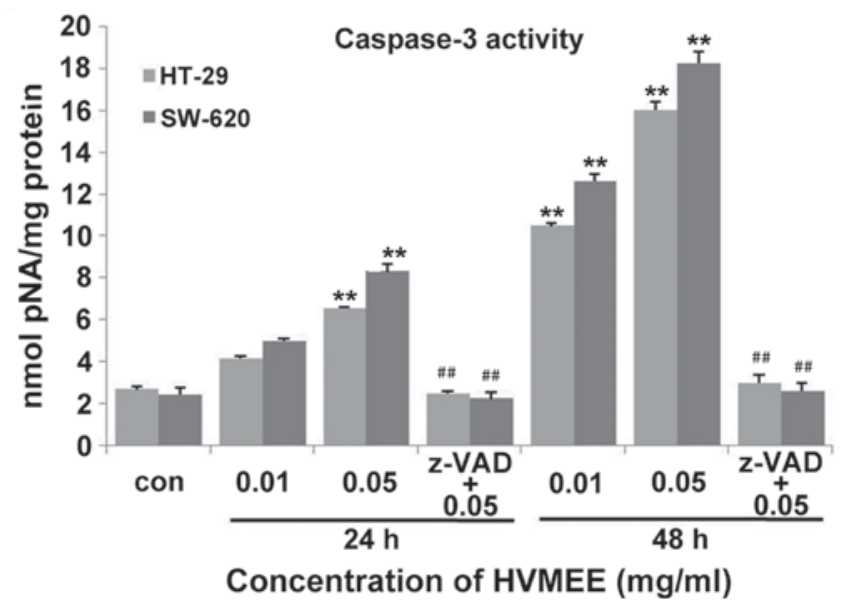

Figure 4. Effect of HVMEE treatment on caspase-3 activity. HT-29 and SW620 cells were treated with 0.01 or $0.05 \mathrm{mg} / \mathrm{ml} \mathrm{HVMEE} \mathrm{for} 24$ or $48 \mathrm{~h}$, following which caspase-3 activity was measured. Treatment with the general caspase inhibitor Z-VAD-FMK $(10 \mu \mathrm{M})$ for $24 \mathrm{~h}$ or $48 \mathrm{~h}$ with $0.05 \mathrm{mg} / \mathrm{ml}$ HVMEE. ${ }^{* *} \mathrm{P}<0.01$ vs. untreated control cells. ${ }^{\# \#} \mathrm{P}<0.01$ vs. treatment with $0.05 \mathrm{mg} / \mathrm{ml}$ HVMEE. The experiment was repeated independently three times. HVMEE, Hylomecon vernalis Maxim. ethanol extract; pNA, p-nitroaniline; Z-VAD-FMK, N-Benzyloxycarbonyl-Val-Ala-Asp(O-Me) fluoromethyl ketone.

treatment in HT-29 and SW620 cells, expression levels of several apoptosis-related proteins were examined by western blotting (Fig. 6A and B, respectively). Expression levels of pro-apoptotic proteins cleaved caspase-3, cleaved caspase-9, and Bax increased in HVMEE-treated cells compared with untreated cells (Fig. 6). Expression levels of cleaved caspase-8 presented no significant change (Fig. 6). By contrast, expression levels of Bcl-2, an apoptosis inhibitor and a central regulator of caspase activation, significantly decreased in the HVMEE-treated cells compared with untreated cells (Fig. 6).

HVMEE affects cell cycle-related protein expression. To test the mechanisms of HVMEE-induced cell cycle arrest, expression of cell cycle-related proteins was further assessed by western blotting. Following treatment of HT-29 and SW620 cells with 0.01 and $0.05 \mathrm{mg} / \mathrm{ml} \mathrm{HVMEE} \mathrm{for} 24$ and $48 \mathrm{~h}$, the expression levels of cyclin D1, cyclin dependent kinase (CDK) 4, and CDK6 decreased significantly in HVMEE-treated cells compared with the untreated cells (Fig. 7). By contrast, protein expression levels of cyclin dependent kinase inhibitor 1A (known as p21) were significantly upregulated in the HVMEE-treated cells compared with the untreated cells (Fig. 7). Since induction of p21 leads to $\mathrm{CDK}$ inhibition and cell cycle arrest at the $\mathrm{G}_{1} / \mathrm{S}$ checkpoint (9-11), these data indicate that the HVMEE-induced $\mathrm{G}_{1}$ phase arrest may be due to inhibition of CDK4/6-cyclin D1 complexes by p21 upregulation.

\section{Discussion}

Apoptosis is an important process to maintain tissue homeostasis by eliminating potentially deleterious cells. Deregulated apoptotic cell death causes diseases, such as cancer. In cancer cells, the incidence of apoptosis and the rate of cell proliferation are uncontrolled $(12,13)$. Therefore, inducing
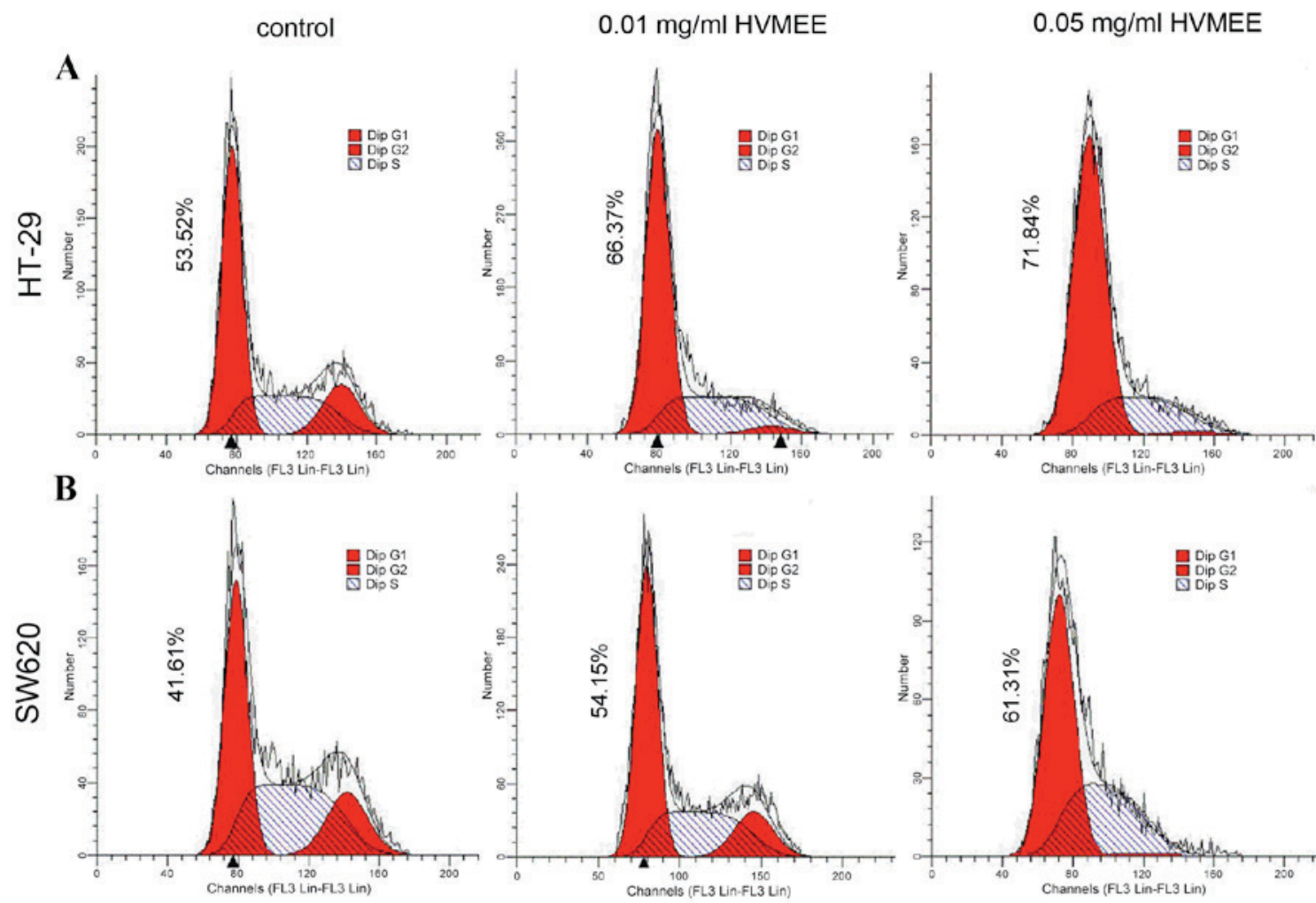

Figure 5. Effect of HVMEE treatment on cell cycle phase distribution. (A) HT29 and (B) SW620 cells were treated with $0,0.01$ or $0.05 \mathrm{mg} / \mathrm{ml} \mathrm{HVMEE} \mathrm{for}$ $24 \mathrm{~h}$, and cell cycle phase distribution was analyzed by flow cytometry. Numbers in the plots denote the \% of total cells in the G1 phase. The experiment was repeated independently three times. HVMEE, Hylomecon vernalis Maxim. ethanol extract. 

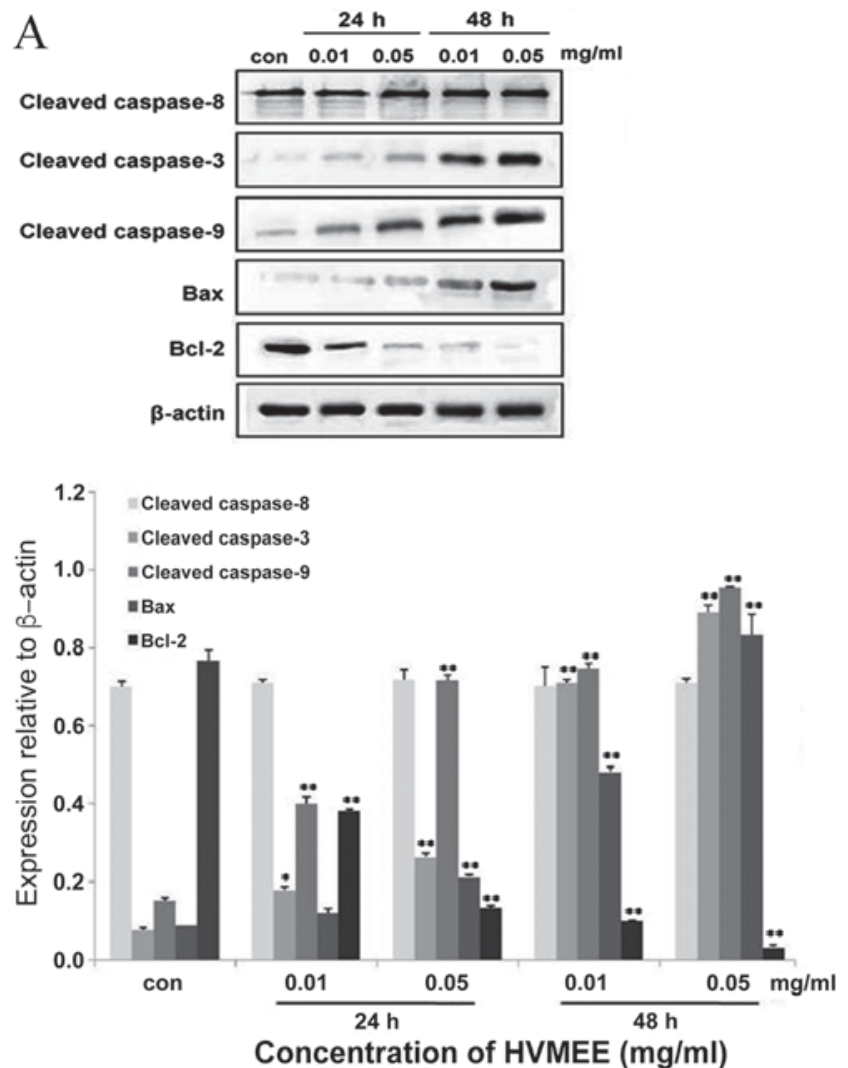

$\mathrm{B}$
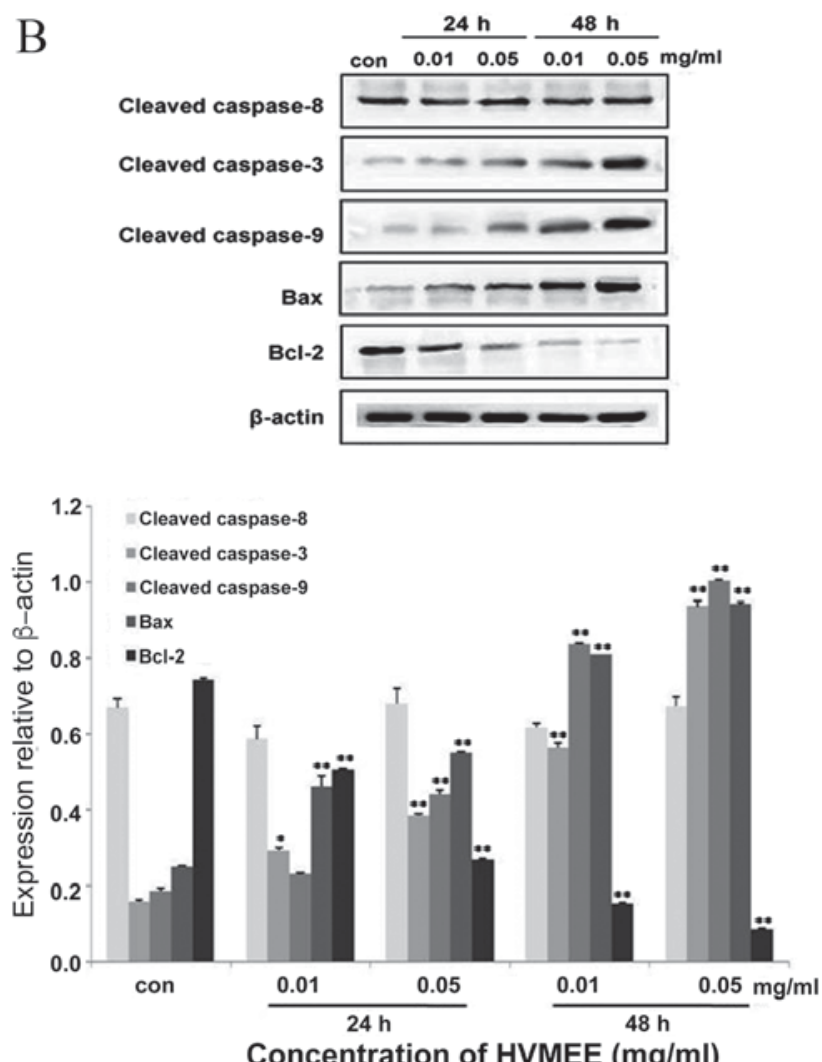

Concentration of HVMEE $(\mathrm{mg} / \mathrm{ml})$

Figure 6. Effect of HVMEE treatment on apoptosis-related protein expression. (A) HT29 and (B) SW620 cells were treated with $0.01 \mathrm{or} 0.05 \mathrm{mg} / \mathrm{ml} \mathrm{HVMEE}$ for 24 and $48 \mathrm{~h}$, then expression levels of apoptosis-related proteins cleaved caspase- $3,-8,-9$, Bax and Bcl-2 were examined by western blotting. $\beta$-actin was used as an internal reference for normalization of signals. ${ }^{*} \mathrm{P}<0.05$ and ${ }^{* *} \mathrm{P}<0.01$ vs. untreated control cells. HVMEE, Hylomecon vernalis Maxim. ethanol extract; Bcl-2, BCL2 apoptosis regulator; Bax, BCL2 associated X apoptosis regulator. The experiment was repeated independently three times.

A
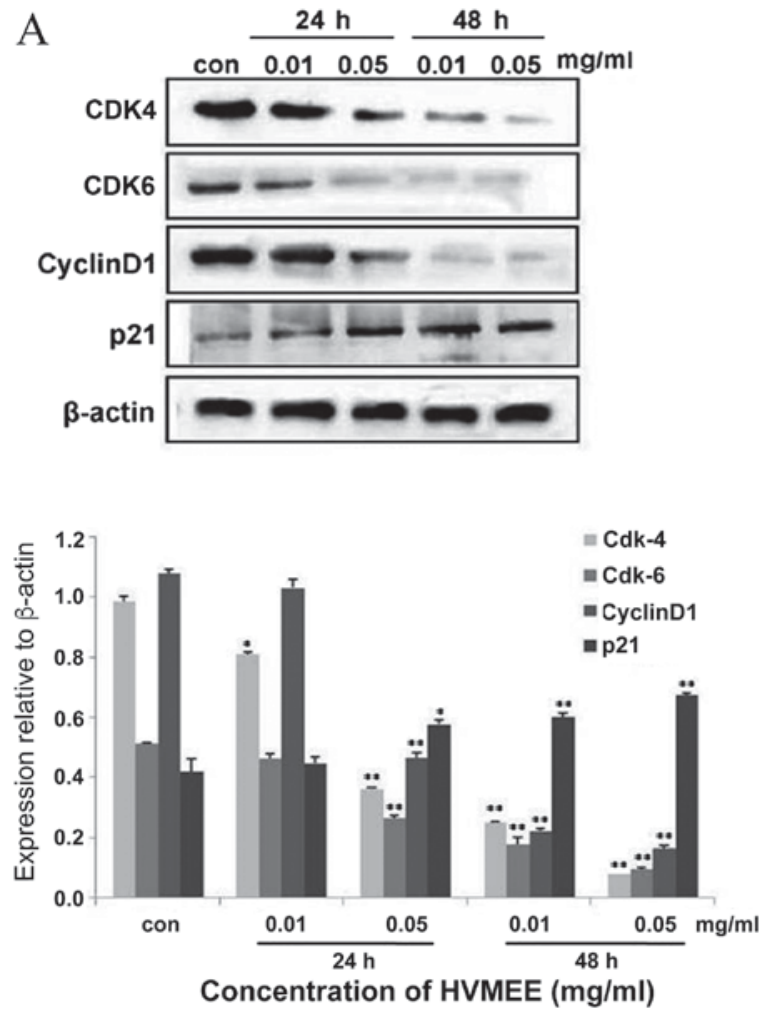

B
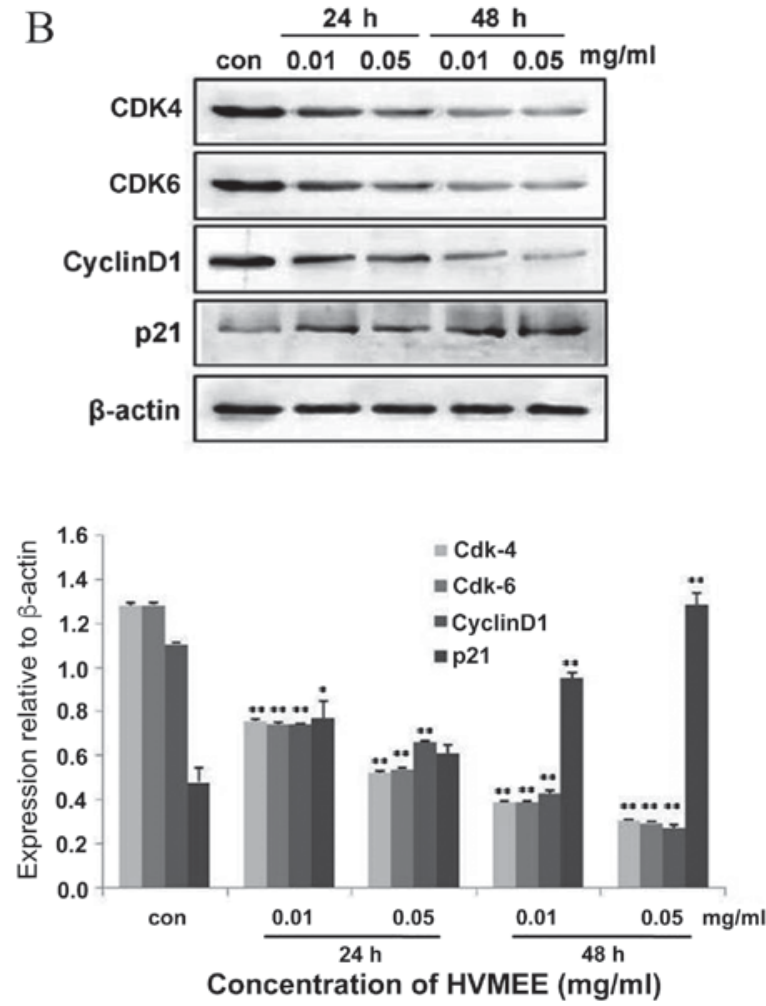

Figure 7. Effect of HVMEE treatment on cell cycle-related protein expression. (A) HT29 and (B) SW620 cells were treated with $0.01 \mathrm{or} 0.05 \mathrm{mg} / \mathrm{ml} \mathrm{HVMEE}$ for 24 and $48 \mathrm{~h}$, then expression levels of cell cycle-related proteins CDK4, CDK6, cyclin D1 and p21 were examined by western blotting. ${ }^{*} \mathrm{P}<0.05$ and ${ }^{* *} \mathrm{P}<0.01$ vs. untreated control cells. HVMEE, Hylomecon vernalis Maxim. ethanol extract; CDK, cyclin dependent kinase; p21, cyclin dependent kinase inhibitor 1A. The experiment was repeated independently three times. 
apoptosis is a potential method of treating cancer. Several chemotherapy drugs, including 5-FU, irinotecan, and oxaliplatin, display anticancer effects partly by inducing apoptosis in cancer cells (14-16). In addition, many alkaloids, such as 6-Acetonyldihydrochelery thrine, piperine, and monoterpene bisindole alkaloids, exert antitumor functions by affecting apoptosis (14-16). In the present study, flow cytometry was used to analyze the effects of HVMEE on apoptosis of colon cancer cell lines HT-29 and SW620. The HT-29 cell line originated from the primary tumor tissue of a colorectal cancer patient, while the SW620 cell line originated from a lymph node metastatic site of a colorectal cancer patient with a Dukes' C classification $(17,18)$. Therefore, these two cell lines were selected to test the effects of HVMEE in order to represent the two different states of colorectal cancer, at the primary and the metastatic stage, respectively. The findings from the MTT and flow cytometry assays demonstrated that HVMEE exhibited a more potent effect on HT-29 cells than SW620 cells, indicating that HVMEE may be more efficient in treating primary rather than metastatic colorectal cancer.

Caspases, a family of cysteine proteases, are central regulators of apoptosis. Caspase- 8 is involved in the death receptor apoptotic pathway and caspase-9 is involved in the mitochondrial apoptotic pathway. Following activation, they cleave and activate downstream effectors, such as caspase-3, which subsequently cleave cytoskeletal and nuclear proteins (19). Western blot analysis demonstrated that HVMEE treatment increased the expression levels of cleaved caspase-3 and -9, but had no significant effect on expression of cleaved caspase-8. HVMEE-induced caspase-3 cleavage was prevented by pretreatment of HT-29 and SW620 cells with a pan-caspase inhibitor, Z-VAD-FMK. These data suggest that HVMEE induced apoptosis in CRC cells in a caspase-dependent manner.

The Bcl-2 protein family, which is important in the mitochondrial apoptotic pathway and whose abnormal expression is related to the development of CRC (20), is divided into two functional subfamilies: Anti-apoptotic proteins [(Bcl-2 and BCL2-like 1 (Bcl-xL)] and pro-apoptotic proteins [(Bax and BH3 interacting domain death agonist (Bid)] $(21,22)$. HVMEE greatly reduced $\mathrm{Bcl}-2$ expression and increased Bax expression in a time and concentration-dependent manner, suggesting that HVMEE triggered apoptosis in CRC cells by regulating the $\mathrm{Bax} / \mathrm{Bcl}-2$ protein ratio.

The transition from one cell cycle phase to another occurs in an orderly fashion and is regulated by two types of important components: Cyclins and CDKs. Different cyclins reach their maximum activity levels during different phases of the cell cycle $(23,24)$. In the present study, HVMEE treatment was demonstrated to trigger $G_{1}$ phase arrest. In order to explore the mechanism, expression of proteins associated with $G_{1}$ phase transition was further investigated. Cyclin D1 is overexpressed in many human cancers, including CRC, and it binds to CDK4 and CDK6 to form a CDK4/6-cyclin D1 complex, which is essential for cells to enter the $\mathrm{G}_{1}$ phase (9). Western blot analysis demonstrated that HVMEE treatment decreased expression levels of cyclin D1, CDK4, and CDK6 compared to untreated cells. p21, which prevents the replication of damaged DNA, is important in CDK inhibition and $\mathrm{G}_{1}$ phase arrest $(10,11)$. HVMEE treatment increased p21 expression compared with untreated cells. Therefore, HVMEE may induce $\mathrm{G}_{1}$ arrest in
CRC cells partly through upregulation of p21 expression. Of note, p53 expression levels in HVMEE-treated HT-29 and SW620 cells exhibited no significant change compared with the untreated cells (data not shown). HT-29 cells have a mutant p53 gene which suggests that p53 may not be as significant in cell cycle and apoptosis regulation in HT-29 cells (25). Taken together, these findings imply that HVMEE induced cell cycle apoptosis and arrest in a p53-independent manner.

In conclusion, HVMEE was obtained from Hylomecon vernalis and demonstrated to exhibit a potent growth inhibitory effect in HT-29 and SW620 colorectal carcinoma cells. The possible mechanism of HVMEE antitumor effect may be related to inducing apoptosis and $\mathrm{G}_{1}$ phase arrest. These data suggest that HVMEE may have potential in the clinical prevention and treatment of colon cancer.

\section{Acknowledgements}

The present investigation was supported by The Project of Science and Technology Research and Development of Shaanxi Province (grant nos. 2012SF2-07 and 2013KJXX-71).

\section{References}

1. Ferlay J, Soerjomataram I, Dikshit R, Eser S, Mathers C, Rebelo M, Parkin DM, Forman D and Bray F: Cancer incidence and mortality worldwide: Sources, methods and major patterns in GLOBOCAN 2012. Int J Cancer 136: E359-E386, 2015.

2. Winawer SJ: The multidisciplinary management of gastrointestinal cancer. Colorectal cancer screening. Best Pract Res Clin Gastroenterol 21: 1031-1048, 2007.

3. Baron JA, Cole BF, Sandler RS, Haile RW, Ahnen D, Bresalier R, McKeown-Eyssen G, Summers RW, Rothstein R, Burke CA, et al: A randomized trial of aspirin to prevent colorectal adenomas. $\mathrm{N}$ Engl J Med 348: 891-899, 2003.

4. Liang CH, Liu LF, Shiu LY, Huang YS, Chang LC and Kuo KW: Action of solamargine on TNFs and cisplatin-resistant human lung cancer cells. Biochem Biophys Res Commun 322: 751-758, 2004.

5. Aggarwal BB, Bhardwaj A, Aggarwal RS, Seeram NP, Shishodia $S$ and Takada Y: Role of resveratrol in prevention and therapy of cancer: Preclinical and clinical studies. Anticancer Res 24: 2783-2840, 2004.

6. Yang H, Yin P, Shi Z, Ma Y, Zhao C, Zheng J and Chen T: Sinomenine, a COX-2 inhibitor, induces cell cycle arrest and inhibits growth of human colon carcinoma cells in vitro and in vivo. Oncol Lett 11: 411-418, 2016.

7. Kong LM, Feng T, Wang YY, Li XY, Ye ZN, An T, Qing C, Luo XD and Li Y: Bisleuconothine A, a bisindole alkaloid, inhibits colorectal cancer cell in vitro and in vivo targeting Wnt signaling. Oncotarget 7: 10203-10214, 2016.

8. Li W, Wen C, Bai H, Wang X, Zhang X, Huang L, Yang X, Iwamoto A and Liu H: JNK signaling pathway is involved in piperlongumine-mediated apoptosis in human colorectal cancer HCT116 cells. Oncol Lett 10: 709-715, 2015.

9. Sherr CJ: G1 phase progression: Cycling on cue. Cell 79: 551-555, 1994.

10. Ko LJ and Prives C: p53: Puzzle and paradigm. Genes Dev 10: 1054-1072, 1996.

11. Siliciano JD, Canman CE, Taya Y, Sakaguchi K, Appella E and Kastan MB: DNA damage induces phosphorylation of the amino terminus of p53. Genes Dev 11: 3471-3481, 1997.

12. Rudolf E, Kralova V, Rudolf K and John S: The role of p38 in irinotecan-induced DNA damage and apoptosis of colon cancer cells. Mutat Res 741-742: 27-34, 2013.

13. Arango D, Wilson AJ, Shi Q, Corner GA, Arañes MJ, Nicholas C, Lesser M, Mariadason JM and Augenlicht LH: Molecular mechanisms of action and prediction of response to oxaliplatin in colorectal cancer cells. Br J Cancer 91: 1931-1946, 2004.

14. Mansoor TA, Borralho PM, Luo X, Mulhovo S, Rodrigues CM and Ferreira MJ: 6-Acetonyldihydrochelerythrine is a potent inducer of apoptosis in HCT116 and SW620 colon cancer cells. J Nat Prod 77: 1825-1830, 2014. 
15. Yaffe PB, Power Coombs MR, Doucette CD, Walsh M and Hoskin DW: Piperine, an alkaloid from black pepper, inhibits growth of human colon cancer cells via G1 arrest and apoptosis triggered by endoplasmic reticulum stress. Mol Carcinog 54 1070-1085, 2015.

16. Mansoor TA, Borralho PM, Dewanjee S, Mulhovo S, Rodrigues CM and Ferreira MJ: Monoterpene bisindole alkaloids, from the African medicinal plant Tabernaemontana elegans, induce apoptosis in HCT116 human colon carcinoma cells. J Ethnopharmacol 149: 463-470, 2013.

17. Abdolahad M, Shashaani H, Janmaleki M and Mohajerzadeh S: Silicon nanograss based impedance biosensor for label free detection of rare metastatic cells among primary cancerous colon cells, suitable for more accurate cancer staging. Biosens Bioelectron 59: 151-159, 2014.

18. Jordan A, Scholz R, Schüler J, Wust P and Felix R: Arrhenius analysis of the thermal response of human colonic adenocarcinoma cells in vitro using the multi-target, single-hit and the linear-quadratic model. Int J Hyperthermia 13: 83-88, 1997.

19. Boulares AH, Yakovlev AG, Ivanova V, Stoica BA, Wang G, Iyer S and Smulson M: Role of poly(ADP-ribose) polymerase (PARP) cleavage in apoptosis. Caspase 3-resistant PARP mutant increases rates of apoptosis in transfected cells. J Biol Chem 274 22932-22940, 1999 .
20. Li XF, Liu XF, Yang YY, Liu AY, Zhang MY, Bai XF, Gao H and Guo XG: Correlation study of Bcl-2, B7-H1, EGFR, VEGF and colorectal cancer. Am J Cancer Res 5: 2277-2284, 2015.

21. Koehler BC, Scherr AL, Lorenz S, Urbanik T, Kautz N, Elssner C, Welte S, Bermejo JL, Jäger D and Schulze-Bergkamen H: Beyond cell death-antiapoptotic Bcl-2 proteins regulate migration and invasion of colorectal cancer cells in vitro. PLoS One 8: e76446, 2013

22. Hector S and Prehn JH: Apoptosis signaling proteins as prognostic biomarkers in colorectal cancer: A review. Biochim Biophys Acta 1795: 117-129, 2009.

23. Rowinsky EK, Cazenave LA and Donehower RC: Taxol: A novel investigational antimicrotubule agent. J Natl Cancer Inst 82: $1247-1259,1990$.

24. Hamilton G, Klameth L, Rath B and Thalhammer T: Synergism of cyclin-dependent kinase inhibitors with camptothecin derivatives in small cell lung cancer cell lines. Molecules 19: 2077-2088, 2014

25. Harper JW: Cyclin dependent kinase inhibitors. Cancer Surv 29: 91-107, 1997. 